\title{
The Madness of Imagining New Worlds
}

\author{
Mercedes Ariza, Maria Giovanna Biscu, María Isabel \\ Fernándes García
}

\begin{abstract}
This paper presents some reflections that emerged from a research project developed in the Department of Interdisciplinary Studies in Translation, Languages and Cultures (SITLeC) of the University of Bologna. This three-stage project was based on language mediator training and the teaching/acquisition of intercultural communicative competence through theatre. During an eight-month workshop, a group of Italian students beginners in Spanish - engaged in a series of extracurricular activities, resulting in the public performance of a play written in verse by Lope de Vega. Under the researchers' supervision, students analysed the play from a linguistic and (inter)cultural perspective, giving special emphasis to the discovery of the other, the encounter of the Old and the New World and the miscommunication caused by lack of understanding in intercultural situations. All these aspects helped students to explore a wide range of verbal and nonverbal communicative strategies, as well as to increase their foreign language proficiency and develop empathy. The in-depth analysis of the play and of the emblematic character of Columbus, whose imagination is capable of inventing new worlds even before discovering them, showed students that the real shipwreck in intercultural encounters is incommunicability itself and that, in order to communicate, one needs to be an 'apostate translator'.
\end{abstract}

\section{Introduction}

The words in the title of this paper interweave and merge with the simple action of opening a book entitled El Nuevo Mundo descubierto por Cristóbal Colón (The New World Discovered by Christopher Columbus, henceforth The New World). Our keen interest in this seventeenth-century play, written by the Spanish dramatist, Lope de Vega, and based on the discovery of the New World by Christopher Columbus, induced us to read its classical verse in a contemporary here and now.

Although it is not easy to reproduce in these few pages the 'mess' of a year spent side by side with Lope de Vega, who taught us how to live in a "disordered order" (Rozas 1976), we will attempt to explain the dramaturgic approach that 
we adopted for the analysis of the play and for the staging of our performance in Spanish.

Like victims of an outer force, oblivious to reason and led by Lope de Vega as a Master, a group of young Italian students was thrown onto the stage. ${ }^{2}$ The youthful passion of our readers/actors, all in their twenties, could not disguise the real challenge underlying our workshop: the majority of students were beginners in Spanish as a foreign language, while only a few of them had ever acted on stage. Moreover, to complicate matters further, only a tiny minority of our Italian audience could understand the harmonious melodies of Spanish verse.

Against this background, this paper aims to describe the crossing that led us to make landfall in the performance of The New World, ${ }^{3}$ and to address theoretical questions relating to language mediation and intercultural communication, as well as some practical issues we encountered during the workshop. ${ }^{4}$ After a brief explanation of the reasons why we decided to work on Lope de Vega's play ( $(2)$, we introduce the concept of the 'apostate translator' ( $(3)$, which arises from some reflections on the translator and his/her relationship with/in the text. In the next two sections, some features related to the performance of The New World are discussed, paying particular attention to the textual and stage architecture ( $\S 4$ ) and to the way in which nonverbal aspects of communication are combined with verse (§5). Sections 6 and 7 focus on intercultural communication and the importance of mediation in the encounter between the Old and the New World.

\footnotetext{
${ }^{2}$ Luciano Baldan, Carla Bondì, Chiara Castagnini, Renee Castiglione, Cinzia Catana, Dalila Crobu, Mara De Col, Valeria Di Giacomo, Mirella Facchinetti, Elisa Fusconi, Federica Mazzocconi, Letizia Montroni, Adele Paolicelli, Luana Rupi, Lucia Zardi. All students attended the Advanced School for Interpreters and Translators of the University of Bologna at Forlì (SSLMIT).

3 The play was performed on 18th of May, 2005 at the Cantiere Internazionale Teatro Giovani (6th Edition), a cultural event organised by the city of Forlì, the "Diego Fabbri" Theatre and the International Theatre Center of New England (USA), together with the Centre for Theatre Studies of the SITLeC Department (University of Bologna at Forli), the Department of Drama, Art and Music Studies (DAMS, University of Bologna), Harvard University and Columbia University. Artistic directors: Franco Fabbri and Walter Valeri.

${ }^{4}$ In the second phase of our three-stage research project, the corpus of dramatic texts selected during the first phase was put to use in two different domains: an "Oral language mediation" module (SSLMIT, University of Bologna at Forlì - curricular training) and a theatre workshop (Centre for Theatre Studies, SITLeC Department - extracurricular training). This contribution refers only to the experiments carried out during the university theatre workshop. The workshop lasted for the whole academic year (October 2004 - May 2005); for the first six months, meetings were held once a week; from March on, they became more frequent (up to three sessions a week in May, before the performance). Since the workshop was offered as a voluntary extracurricular activity, meetings took place during the evening. The activities were coordinated by Claudio Bendazzoli together with the paper's authors. For a detailed description of the stages involved in the research project see Fernández García \& Biscu (2005/2006).
} 


\section{Christopher Columbus in the Mirrors Room}

Christopher Columbus was the special guest at the events and activities organised by the Centre for Theatre Studies of the SITLeC Department for the academic year 2004/2005. We were fascinated by the visionary boldness of the Genoese Admiral, who eventually discovered what he had imagined. Moreover, Columbus' determination coincided with one of the basic training purposes for our students/future language mediators: developing ways of thinking through images (Fernández García 2000). In the loneliness of the ocean, the left and right hemispheres of our discoverer were teeming with geometric lines of found or invented maps, echoes of unknown languages and rhythms, the smell of spices with their golden sparks. The figure of Columbus, seen not only as a historic character but also as a man, was shrouded in mist; his loneliness hidden in the following lines - enchanted us with irresistible power:

Imaginación.

- ¿Qué es lo que piensas Colón que el compás doblas y juntas?

Colón. ¿Quién eres, que lo preguntas?

Imaginación.

. Tu propia imaginación. ${ }^{5}$ (vv. 688-691)

From that moment on, all our doubts disappeared: we knew we would have to put on stage Lope de Vega's play. The dialogue/monologue "¿Qué es lo que piensas Colón?" (v. 688) - emerging from solitude - visualises/materialises the birth of madness: the impossibility of experiencing the vivid images of our inner landscapes in so-called reality. In other words, this stands for the need to invent a world in which what we imagine overlaps with what we really desire.

In the Mirrors Room, ${ }^{6}$ the Columbus created by Lope de Vega struggles to invent a world in which the man who is "poor and wise" ("el hombre que es pobre y sabio", v. 692) can die with fame, without being hungry and dishonoured. Several elements constitute mirror-images of Columbus' madness: Marco Polo and his Il Milione - a commercial treaty, according to Umberto Eco (1985: 61); stolen or manipulated maps; the dying pilot from Madeira and his secret. ${ }^{7}$ All in all, Lope de Vega's Columbus acts like a crook, a spy, a master and a servant of himself, a man who needs money to live in the appearance of reality what he has already experienced in his cabin while reading. In order to live his adventure, Columbus needs a patron and an ocean; in return, the Spanish Crown - patron of the Admiral's madness - will obtain gold, silver, precious stones and, of course, the conversion of the Indians from Idolatry to Catholicism. In the year the Moorish Granada falls, the Catholic Monarchs soon welcome Columbus'

\footnotetext{
${ }^{5}$ We follow the edition of Lemartinel \& Minguet (1980). To facilitate understanding of the examples quoted, we offer a translation of Lope de Vega's verse. "Imagination. What are you thinking about, Columbus? / You don't stop opening and closing your pair of compasses. / Columbus. Who are you who asks this? / Imagination. Your own imagination."

7 In the first act, Columbus describes to the King of Portugal his encounter with a dying pilot, who gave him some maps that proved the existence of new worlds. Columbus believed the sailor's account because a person about to die cannot sell the truth, but only reveal it.
} 
proposal, as if they want to find a good economic receipt for their kingdom after a long war.

Lope de Vega's Columbus, a Genoese without a bank, an "ordinary" Italian sailor (Restall 2003), succeeds in finding money for his ship of fools. ${ }^{8}$ When he gets to the desired land, when he invades the imagined space, Columbus discovers what he had never dared to imagine: the other. The mirror does not reflect his loneliness any more, his certainties founder and words become segmented, twisted, and lead him to the following conclusion: in order to communicate, one needs to be an apostate translator (see next section), as exemplified by Sabbatai Zevi, ${ }^{9}$ a Jewish Messiah converted to Islam (Scholem 2001).

\section{The Apostate Translator}

To explain the translation process of one system into another, Fabbri (2003) puts forth an example taken from the history of religions: the life of Sabbatai Zevi, who died in exile, as a Jew and a Muslim. This example can be considered as a demonstration that paradigms are flexible because they can be translated (Fabbri 2003: 100-101; Boothman 2004: 126-128); what seems to be untranslatable at first sight, may become the source of information for future translations (Lotman 1999: 37-38).

Similarly, if we apply this reasoning to interlinguistic and intercultural translation, we may interpret the capability of the translator to be in two places at the same time, during the translation process, as an act of apostasy. This pushes the issue of empathy to the utmost limit and makes it clear that the translator always has to give up some elements relating to his/her system of social, cultural and linguistic values to embrace other systems of values. As we will explain later on $(\S 6)$, the only way to survive in this situation is through communication, mediation and dialogue.

Columbus' thoughts, transformed into poetry by Lope de Vega, helped future language mediators learn that their loneliness while coping with the text can be fertile if they allow their imagination to enter a dialogue with the enunciator of the text. Accordingly, the enunciator should not be considered as an extrinsic instance that precedes the text. In fact, as Lotman explains in Texto y Contexto (1980), the enunciator is the result of the text, and the marks that $s /$ he leaves can be used to retrace his/her own presence within the text itself.

For this reason, one cannot avoid addressing the following question: how is it possible to recreate the enunciator from the text? Or, in simpler words, how is it possible to make the text display itself? Fabbri (2003) has argued that this process is based on the ability to spot the interpretations and distortions allowed by the text, as well as the simulacra of enunciator and enunciatee that arise from the textual mesh (Fabbri 2003: 57). After wandering across

\footnotetext{
9 This prophet - born in Smyrna in 1626 - was believed to be a Jewish Messiah; after having been imprisoned in Gallipoli, he converted to Islam and died exiled in Dulcigno in 1676.
} 
textual labyrinths, the translator neither adapts nor adopts the text; on the contrary, we can state that the text adopts the translator as a new enunciator: to paraphrase Sanchis Sinisterra (2002: 176-177), the translator is the text's adoptive enunciator. The loneliness of the translator with/in the text already lives inside the text, because his/her dialogue with the original enunciator is already a translation (Lotman 1985).

If we go back to the image of the apostate translator, we may observe that this figure represents one of the challenges of recent translation studies, i.e. intercultural translation:

Fino a che punto si può davvero tradurre l'esperienza di una società coloniale da una posizione interna alla cultura del paese imperialista visto che i loro rapporti di produzione ed i fattori superstrutturali sono ampiamente diversi? E che dire della traduzione di esperienza di genere e/o etniche? [...] "diventare indigeno" è la soluzione proposta per uscire da tali dilemmi. ${ }^{10}$ (Boothman 2004: 127)

For this reason, the decision to plunge our future language mediators into a Colonial play as The New World gave us the opportunity to transform a theoretical challenge into a real-life experience. According to Boothman, conflicts due to untranslatability can be solved when one integrates the intellectual activity with the ability to perceive and feel the other, following a path which leads to comprehension, and consequently to interpretation. Without this premise, no community can try to translate somebody else's experience (Boothman 2004: 128-129).

As far as intercultural communication is concerned, the first theoretical and practical question addressed by our research project is whether intercultural communicative competence can be taught/acquired in a university classroom context (Fernández García \& Biscu 2005/2006: 329). We have tried to give a concrete answer to this question by offering an innovative teaching practice that applies specific drama and theatre activities to language mediator training. ${ }^{11}$ As we will see in the following sections (and, in particular, in § 5), Lope de Vega's play gave us the opportunity to make our students perceive, feel, understand,

\footnotetext{
10 To what extent can the experience of a Colonial society be truly translated from the culture of an Imperialist country, considering that their relations of production and their superstructural features are extremely different? And what about the translation of gender and/or ethnic experiences? [...] the solution proposed to solve these dilemmas is "to become indigenous." (our translation).

${ }^{11}$ Although there is an extensive literature concerning the teaching and learning of foreign languages, literature and grammar through drama, much needs to be done in the field of language mediator (interpreter and translator) training. Our research project, which combines drama and theatre-in-education with intercultural communication, is an attempt to fill this gap. In particular, the extracurricular activities proposed during the workshop made students aware of the special emphasis that should be put not only on the process but also on the final product (as it happens while translating a text). Therefore, the performance before a live audience (mainly made up of teachers, relatives and friends) is an integral part of the training process and fosters students' motivation and their willingness to improve their verbal and nonverbal communication and their (inter)cultural communicative competence.
} 
interpret and translate the emotion of the Indian of Guanahamí under their own skin.

In this New World, the translator is the Messiah because s/he saves people from the lack of communication; the figure of the traitor/translator of images conveys the salvific message in the Mirrors Room. Our decision to put on stage The New World converted us into apostate translators of Lope de Vega's poetic world.

The architecture of our dramaturgic experiment resulted in another mirror image: we designed a backcloth consisting of a virtual book, whose pages turned over at every scene; as the book of the virtual backcloth opened, Lope de Vega's verse became a real substance. Moreover, our adaptation of the play opened with a virtual prologue consisting of a two-minute video that started with a close-up of Columbus' eyes; ${ }^{12}$ through this image, the audience could penetrate the Admiral's thoughts, his desire to discover new worlds and the contradictions contained in the encounter between the Old and the New World. A series of digital images merged with voices, maps and dreams and slid into the sea through a tunnel till they stumbled upon the existence of an invented land. At the end of the Third Act (when the Catholic Monarchs are given the first fruits of the New World, v. 2924), we decided to show our prologue backwards, while Hakim - a young friend from Morocco - asked in Arabic: "What are you thinking about, Columbus?". This raised the question of whether the actions of our crossing/reading/stage life took place only in the imagination of the Genoese sailor.

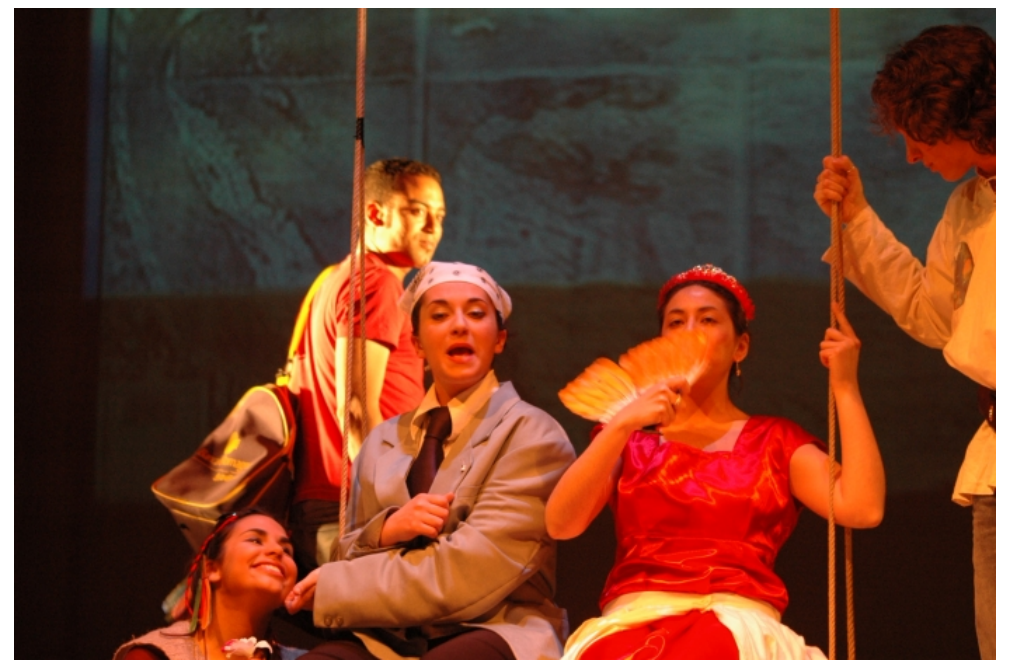

Figure 1: "What are you thinking about, Columbus?" (End of Act III)

In order to contextualise the discovering of the other and its intercultural implications, we also decided to insert a scene taken from the short play "La Falsa muerte de Jaro el Negro", by Martín Iniesta (1997), whose main theme is

\footnotetext{
12 The video and the virtual backcloth were made by Luciano Baldan, the student/actor who played the character of Columbus.
} 
racism and xenophobia. ${ }^{13}$ Students had already worked on this play during the first meetings of the workshop, and we all agreed to ask Hakim to play Jaro's role. Before the beginning of the performance, Hakim was supposed to try and sell paper handkerchiefs to the audience, as Jaro does in the prologue of the short play. Unfortunately, an usher who did not catch what was happening misinterpreted our stage pretence, offering a scene that was not provided for by the script: he expelled Hakim from the stalls and he actually threatened him as if he were the madman of the raft that came to invade our 'privileged space'.

\section{Textual and Stage Architecture}

As already stressed in the previous section, the encounter with/in the text in loneliness allows us to inhabit a space that, in our specific case, rises from the power of verse. Poetry and rhyme, with their simultaneous linearity, create a three-dimensional image that enables the reader/actor to listen to faraway sounds and to move, at the same time, in different spaces (this means that while reading the third verse, it is possible to come back to the first one, Fabbri 2001: 83). We believe that the architecture of a play written in verse proceeds precisely from that flexibility. Dramatic poetry acts as a magnifying glass that focuses and widens the triadic structure of communication, "which exists only as a verbal-paralinguistic-kinesic continuum formed by sounds and silences and movements and stills" (Poyatos 2002a: 103). This capability of verse to make visible what cannot be read or seen (Poyatos 2002b) implies significant consequences for the staging of a play, since the enunciator leaves his/her mark in every rhyme. Besides stage directions, the enunciator explains to us how $\mathrm{s} /$ he views the action $\mathrm{s} / \mathrm{he}$ is showing and, most of all, how s/he wants the audience to listen and to see it (Thürlemann 1980).

The following example may be helpful to understand this process in The New World. Throughout the play, Lope de Vega never uses the word invasion, although the idea of invasion is suggested by the way in which the actions are staged. The stage space is presented, without any doubt, as an invasion of the space of the other. From a semantic and cultural point of view, the words invasion, arrival, conquest, discovery imply a completely different textual enunciator. For this reason, Lope de Vega's dramaturgical strategy and his description of the arrival of the Spaniards from the native's perspective assumes great importance: the cry of "Land" and the following action of landing are the result of an invasion that affects firstly the sound space of the island, and secondly the visual space and the Indians' social environment (the Spaniards arrive just when the cacique Dulcanquellín, the ruler of the natives, is about to get married to the indigenous Tacuana).

In this respect, it is interesting to point out that our invasion of the play led us to conceive an image of the stage space that, for another mirror game, matched

\footnotetext{
13 This scene was played by our friend Hakim Abdelatif Faouzi and by Chadi Monti, a former student of the Advanced School for Interpreters and Translators (University of Bologna at Forli).
} 
with the analysis of Lope de Vega's dramatic text carried out by Teresa Kirschner (1993). Our stage architecture (Figure 2) is characterised by six well-defined areas:

1. the invisible caravels: the sea of the unexplored;

2. the throne/swing: presence of the powers of hereafter (más acá);

3. the cross/pyramid: presence of the powers of herebefore (más allá);

4. the hammock: presence of evil;

5. the nuptial bed: the meeting space;

6. the land of the island/stalls: presence of the Indian audience.

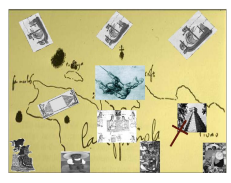

Figure 2: Scheme of the stage space

What were the consequences of this stage framework for our students/actors? The first consequence was a practical one, since this helped them to visualise entrances and exits; accordingly, they realised which was the direction towards which they had to turn their energy bundle. Thus, they could almost see the vector of their movement and its track. Moreover, the shifts of their glances expanded the borders of the imaginary territory causing invasions/intersections. Another major consequence was the acknowledgment that the space of interaction between the two worlds was a mediation space. During the performance, as a result of the three-dimensional model of the poetic image, one of the Indian female characters called Palca - a cultural and language mediator by profession, as will be explained in $\S 7$ - eventually occupied the space of the throne/swing of power.

However, the most important thing was, beyond doubt, the fact that we decided to identify the audience and the stalls with wild Indians. This choice was of considerable practical significance for our students/actors, since the expedient of transforming the audience into a character contributed to recreating the relationship of complicity that the original text established with the audience through irony. Consequently, this dramatisation of the stalls led to the materialisation of a community of speakers, which continues to exist as long as it takes place in the mental space of interacting speakers. The reception of theatre and its perception potential seem to be a good laboratory in which to put this theoretical statement to the test.

As well as providing instruments to inhabit the stage architecture devised by Lope de Vega, the powerful verse of The New World was the key element to 
access and explore the kinesic aspects of communication (Poyatos 2002a). To explain this, we need to go back to the lines "¿Qué es lo que piensas Colón / que el compás doblas y juntas?” (vv. 688-689, see § 2).

Although the compasses are mentioned only three times in the play, they are the symbol of Columbus' mental images and a visual representation of his projects and inner desires. In the play they appear as a still and flexible sculpture; on the stage, this still element accumulates potential action and tension, undergoing a perpetual metamorphosis. This chameleonic ability has transformed the compasses in the following elements: a weapon and a sword for war and seduction; a flag and a banner after the conquest of the New World; a generator of dance and musical geometry. During the performance, the wooden compasses used by the students/actors present on stage acquire different meanings, depending on the communicative purpose. Moreover, the legs and arms of four dancers could be seen as human compasses, thus supporting the idea that the verse is strictly related to the above-mentioned basic triple structure of communication. Indeed, the students/future language mediators who played a pair of compasses may well remember this theoretical principle.

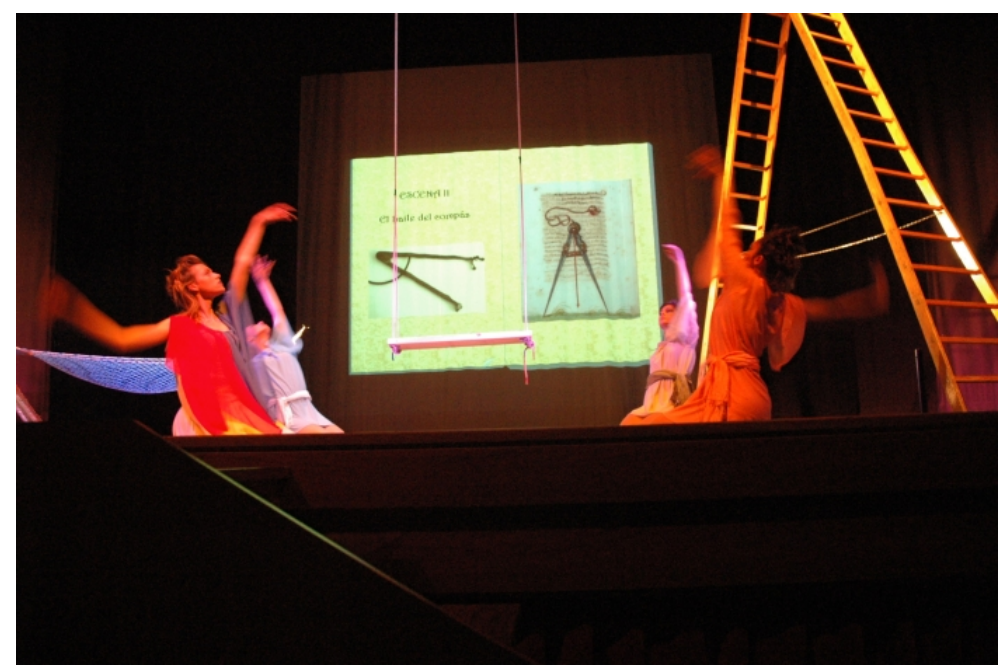

Figure 3: The compasses and their perpetual metamorphosis (Act I)

\section{The Gesture in the Verse / The Verse in the Gesture}

The question of meaning introduces us to the field of intercultural translation and, consequently, to the competencies and skills needed to confront it. 'Discovering the other' implies the development of empathy (Rodrigo Alsina 1999: 79) and self-observation, which are necessary steps to feel someone else's emotions. Considering all of that, we devoted a central part of our workshop to the analysis of the artistic artefacts and iconography of Pre-Columbian cultures. We imagined the Indian gestures accompanying the words spoken 
by the characters and, in parallel, we could not separate such gestures from the way of perceiving and feeling the Indian reality. Although all characters in The New World express themselves through the Spanish verse, ${ }^{14}$ Lope de Vega suggests that the Indians and the Spaniards do not share the same linguistic code. The Spanish dramatist often makes reference to the fact that the Indians ignore not only the language but also the commodities of European life and the values of the Catholic faith; he is a Master in creating situations based on communicative flaws, often described with bitter irony.

The fictional nature of theatre allowed our students/actors to assume that even two groups of people who speak the same language may not be able to understand each other. Lope de Vega's representation of the Indians spontaneously guided students to develop alternative (nonverbal) ways of communication, as it happened in the historical event. During the workshop, we did not pay much attention to Lope de Vega's construction of the Indians and to the fact that he portrayed them "within the ideological constructs of blood, nobility, power, faith, love and desire" (Brotherton 1994: 37), as if they were typical Golden Age comedy characters. We rather focused on the intercultural implications of the encounter between the Old and the New World and on the importance of empathy while trying to translate the linguistic and cultural paradigms of the other.

This was one of the most intense and interesting processes from a dramaturgical and intercultural viewpoint: while students/actors studied the material relating to the Caribbean Indians and the Pre-Columbian cultures, they developed their own language. The new alphabet combined with gestures and gazes, modelling a new familiar grammar - opaque to invaders - that never come into conflict with the seventeenth-century Spanish verse. This linguistic resistance was the personal and unexpected discovery made by our students/actors/Indians.

The last scene of the Third Act was representative of this process: sadness grew spontaneously among some students/actors out of the pain caused by exile, and not in response to an imposed stage direction. By living the emotions of the Indians under their own skin, students succeeded in better understanding the other, as well as in developing empathy and self-observation.

\section{Communicative Shipwrecks}

In their metaphoric journey across the text, the ironic and biting verse of Lope de Vega made our students understand that the real shipwreck in intercultural encounters is incommunicability itself. In The New World, misunderstandings and communicative problems are often caused by the lack of shared linguistic and cultural paradigms. Lope de Vega's play left us with an important message:

\footnotetext{
${ }^{14}$ In this regard, many scholars have pointed out that the Indians portrayed by Lope de Vega express themselves through Spanish verse before being discovered (Menéndez Pelayo 1949: 310).
} 


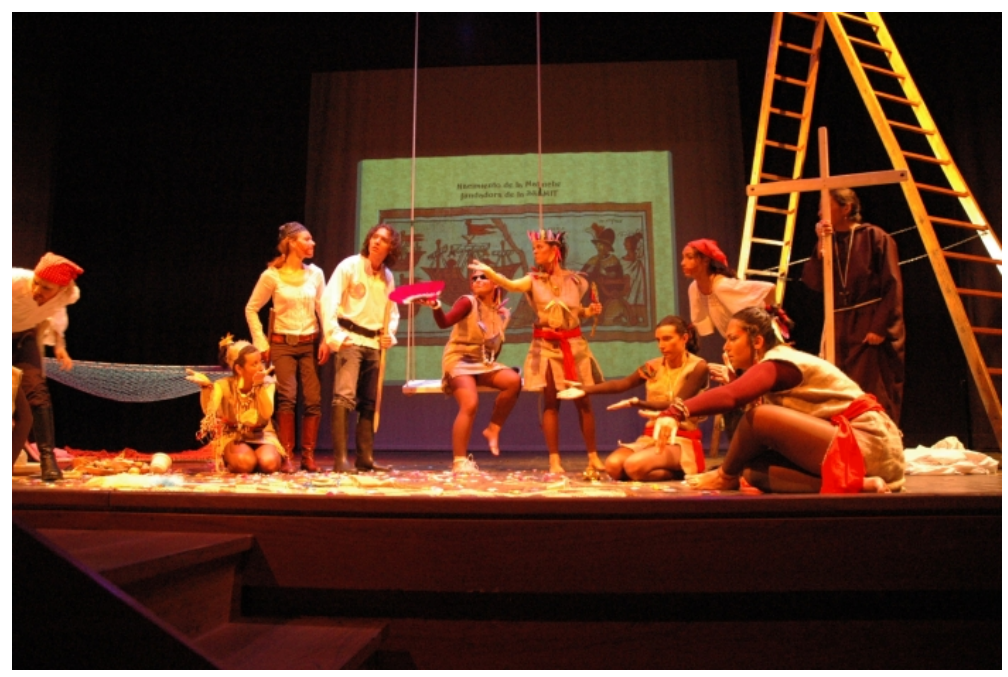

Figure 4: The Old and the New World in gestures (Act II)

when you interpret the reality of the other from your own knowledge paradigms, when you do not enter a dialogue with the other and, therefore, there is no translation, the only possible result is a 'shipwreck'. Nevertheless, the character of Palca, the new Malinche $e^{15}$ of the dramaturgical universe conceived by the Spanish playwright, proves that paradigms are flexible and that communication between two worlds can be achieved through dialogue and mediation.

As we explained in $\S 4$, Lope de Vega represents the arrival of the Spaniards and, therefore, their interpretation of an unknown world, through the Indians' eyes. These vivid and ingenuous descriptions are based on some Chronicles that the author used as a source of information to write his play (Menéndez Pelayo 1949; Shannon 1989). In the second act, communicative shipwrecks start when the Indian character Auté sights caravels among mist and masses of clouds. According to his fanciful narration (vv. 1479-1520), the boats are houses, the skin of people who live in such houses is coloured, the rifles are sticks from which fire and smoke come out. ${ }^{16}$ After this interpretation, the two caciques propose their own versions, which are even more delirious. Dulcanquellín corrects Auté, by claiming that those are not houses but fishes ("Ignorante, ¿qué dices? / peces son, peces que braman", 17 vv. 1521-1522). To show that he is not inferior, Tapirazú - the other cacique - invents an answer for what he does not know, recalling the stories that his grandfather told to him: "Yo sé mejor lo que ha sido, / que estas son reliquias claras / de los gigantes que un tiempo / vinieron a estas montañas"18 (vv. 1531-1534) (Dongu 2004: 85). The Indians clearly perceive the absolute novelty of their visions but they cannot understand them; hence, their only solution is to derive interpretations from their own paradigms.

\footnotetext{
17 "What are you saying, ignorant man? / They are fish, fish that roar."

18 "I have a better idea of what it is, / these are clear traces / of giants that a long time ago / came to these mountains."
} 
The abyss of incommunicability appears to be even more measureless in the first contacts between the Spaniards and the Indians, in which one can observe a complex and funny mixture of signs, gestures and words. From the gestures made by Columbus' crew, Palca guesses that the Spaniards are asking her what her name is and, when she answers, she sets off a series of interpretative and linguistic games aimed at making the audience laugh. As in the following example, the verse expands the comic effect, linking together humour with rhymes:

Palca. iPalca, Palca!

Colón. Lo primero dice Palca.

Bartolomé. ¿Es rey, es hombre? ¿Es la tierra, es guerra o paz?

Palca. El señor pregunta, en fin. Cacique, Dulcanquellín.

Colón. No es de entenderse capaz, que al fin es bárbara lengua.

Bartolomé. Cacique debe de ser, que habrá adentro que comer, y Dulcán, que no habrá mengua. Y por ventura Quellín, será el pan, o será el vino.

Colón. iVino aquí, qué desatino! ${ }^{19}$ (vv. 1659-1673)

Throughout the play, Lope de Vega appears to be a Master for future language mediators, raising the theoretical problem of untranslatability from different viewpoints. As was explained earlier, this problem - that in this specific case is condensed by the word "cacique" - can be solved by patiently fostering dialogue. A century after the discovery, the lack of comprehension of the word "cacique" brings along comical consequences: to interpret this word, Bartolomé invents what his imagination desires, i.e. bread and wine. His extravagant ideas contrast with the visionary sensitivity of Columbus, who does not want to be dragged into the game of deformed mirrors and easy rhymes.

In The New World, the theme of hospitality offers new examples of communicative flaws. At the end of the second act, Columbus asks Dulcanquellín if there is something to eat; the cacique gives his personal interpretation: "Sospecho / que nos piden que comer" 20 (vv. 2002-2003). To demonstrate that he wants to receive his guests with great ceremony, Dulcanquellín orders a banquet of 'native delicacies' to be prepared:

\section{Dulcanquellín.}

19 "Palca. Palca, Palca! / Columbus. First of all / she says Palca. / Bartolomé. Does it mean king, man? / Is it land, war or peace? / Palca. They are asking for our chief. / Cacique, Dulcanquellín. / Columbus. She can't understand, / after all, it's a rough language. / Bartolomé. Cacique must mean, / that there's something to eat inside, / and Dulcán, that it won't be scarce. / And possibly Quellín, / will be bread, or wine. / Columbus. Wine here, that's utter nonsense!"

20 "I suspect / they're asking us for something to eat." 
- Mata, Auté, cuatro criados

de los más gordos que hallares,

y entre silvestres manjares los pon en la mesa asados. ${ }^{21}$ (vv. 2006-2009)

Humour lies in these verses, as Lope de Vega turns to the paradigm of cannibalism (Shannon 1989: 75-76). Carried by this further shipwreck, pervaded by irony, Columbus reacts to the proposal of the cacique by consecrating the land he has just discovered, knowing for certain that the New World will be a source of material and spiritual richness ("Cielos, hoy fundo / la fe en otro mundo nuevo. / España, este mundo os llevo. / iNuevo Mundo!", 22 vv. 2010-2013). The unanimous cry of "New World!" is full of emotion and hope, even though there still remains a suspicion: "this world" of cannibals is (or is not) the paradise of deception.

\section{Palca: A Mediator between the Old and the New World}

Lope de Vega redeems the characters of these shipwrecks through humour, love and mediation. The Indian Palca embodies the first interpreter of the world that Columbus had dreamt of and, subsequently, discovered. In the beginning, she is filled with dread, but soon afterwards Palca seems to communicate perfectly with the Spaniards, and appreciates their "warmth and gentleness"; she tries to interpret the verbal and nonverbal gestures of those "beautiful men" and accepts their gifts with cheerfulness. However, when she looks at herself in the mirror - the strange and foreign object that the Spaniards gave her - Palca returns to her initial dread. That glass reflects not only her face, but also the complex dilemma of otherness.

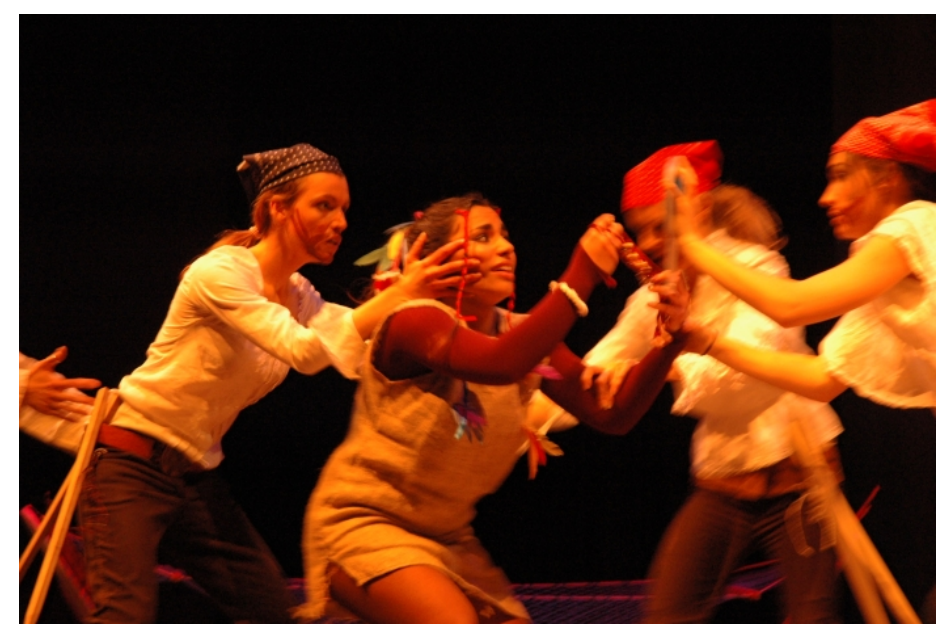

Figure 5: The dilemma of otherness reflected in the mirror (Act II)

\footnotetext{
21 "Dulcanquellín. Auté, kill four servants / choose the fattest you can find, / add some wild delicacies / and serve them roasted on the table."

22 "Heavens above, today I found / the faith in another new world. / Spain, I'll take you this world. / a New World!".
} 
Nevertheless, Palca faces untranslatability and otherness with lively irony, a characteristic that emerges when she calls her people to give them the good news:

Dulcanquellín. Palca, ¿habláronte?

Palca. Pues no.

Dulcanquellín. ¿Qué entendiste?

Palca. Que querían comer, y que aquí os traían

de esto que os mostrase yo.

Dale los cascabeles. ${ }^{23}$ (vv. 1894-1897)

When she declares that the Spaniards did not talk to her, Palca is suggesting that in the first encounter between the Old and the New World - a key moment in our history - there was no communication, i.e. there was no translation. Shortly afterwards, the humour of her declaration makes room for a bitter remark: once again we witness the uncertainty of communication, that anti-myth of the communicative flaw put forward by Restall (2003). In our dramaturgic experiment, Palca gives us hope that, in the end, even completely different worlds can meet. Going back to Lotman (1999), what was firstly considered as untranslatable will become the starting point for future translations, and may even be an incentive for future discovering.

History shows that only the road to mediation can lead to pacific coexistence. Lope de Vega proposes the cross-breeding (mestizaje) ${ }^{24}$ of the Spaniards with the Indians as a method to make the paradigms of knowledge more flexible, by synthesising the hybridity of races, languages and cultures.

\section{Concluding Thoughts}

The threads of incommunicability laced with hunger, utopian dreams and madness force Columbus to go back to the Old World. In this way, he avoids witnessing the chronicle of deception: his absence on stage transforms him into the privileged observer of what the motherland has been trying to cover up since 1577, through the prohibition of the Chronicles from the Indies. ${ }^{25}$ Did Lope de Vega write a play on Columbus as a discoverer because of this silence imposed to guard the secrets and treasures of the Indies? This may not be the

\footnotetext{
23 "Dulcanquellín. Palca, did they talk to you? / Palca. Not at all. / Dulcanquellín. What have you understood? / Palca. That they wanted / to eat, and that they brought us / these things they asked me to show you. She gives them some small bells."

${ }^{24}$ In the Third Act, Lope de Vega puts forward this proposal through the Indian character Tacuana, who concludes her dialogue with one of the Spaniards - to whom she has fallen in love - by saying: "by mixing our blood / we will all be Spanish." ("mezclándose nuestra sangre / seamos todos españoles." (v. 2194-95).

25 In 1577, King Felipe II ordered to confiscate all the letters and Chronicles (especially those written by Hernán Cortés and by the missionary and ethnographer Fray Bernardino de Sahagún) which dealt with social and religious habits of the Caribbean Indians. The reason for such a prohibition was due to the "suspicious themes" displayed in these works, which contrasted with the colonial policy of the Spanish Crown (Baudot 1983).
} 
case, nevertheless we would like to imagine that this is what happened. After all, we agree with those scholars (for example Castells 2000; Shannon 1989) who interpret The New World as a play that gives a rather complex view of the Spanish imperial expansion and that questions the two major reasons for the discovery/conquest of the New World: wealth and religion.

As is the case every year, ${ }^{26}$ after the final curtain call, we were gently caressed by a feeling of nostalgia, a good symptom of madness according to Foucault. A nostalgia for the madness that characterises timeless utopias, but also a nostalgia for the emotions lived in a stage space that was our personal island.

Five centuries after the discovery of the New World, in the globalised world in which we live, wealth and religion still raise problems of communication and of lack of comprehension among peoples. In the meanwhile, our future translators/language mediators will continue inventing new languages (Lozano Miralles 2005).

Acknowledgments - We wish to thank our friend and colleague Claudio Bendazzoli, with whom we share - year by year - that feeling of nostalgia that gently caresses us after every final curtain call.

\section{Bibliography}

Baudot, Georges (1983): Utopía e Historia en México. Los primeros cronistas de la civilización mexicana (1520-1569) (Span. trans.). Madrid: Espasa Calpe

Boothman, Derek (2004): Traducibilità e processi traduttivi. Un caso: A. Gramsci linguista. Perugia: Guerra edizioni

Brotherton, John (1994): "Lope de Vega's El nuevo mundo descubierto por Cristobal Colón: Convention and Ideology". In: Bulletin of the Comediantes, Vol. 46, 1, 33-47

Castells, Ricardo (2000): “Oro e idolatría en El nuevo mundo descubierto por Colón de Lope de Vega". In: Neophilologus, Vol. 84, 3, 385-397

Dongu, Maria Grazia (2004): Naufragi, approdi e ritorni. Morte e rinascita nei drammi spagnoli e inglesi della Conquista. Ravenna: Longo Editore

Eco, Umberto (1985): Sugli specchi e altri saggi. Milano: Bompiani

Fabbri, Paolo (2003): Elogio di Babele. Roma: Meltemi

Fabbri, Paolo (2001): La svolta semiotica. Roma-Bari: Laterza

Fernández García, Isabel (2000): "La formación de intérpretes y los laberintos propedéuticos". In: Melloni, Alessandra; Lozano, Rafael; Capanaga, Pilar (eds.): Interpretar traducir textos de la(s) cultura(s) hispánica(s). Bologna: CLUEB, 445-483

\footnotetext{
${ }^{26}$ For a complete list of the performances prepared by the university Spanish theatre workshop, see Appendix.
} 
Fernández García, Isabel; Biscu, Maria Giovanna (2005/2006). "Theatre in the Acquisition of Intercultural Communicative Competence: The Creation of a Multilingual Corpus of Dramatic Texts for the Training of Future Language Mediators". In: International Journal of Learning, Vol. 12, Issue 10, 327-336 <http://www.Learning-Journal.com>

Foucault, Michel (1967): Madness and Civilization: A History of Insanity in the Age of Reason (Eng. trans.). London-Sydney-Wellington: Tavistock

Greenblatt, Stephen (1991): Marvelous Possessions: the Wonder of the New World. Oxford: Clarendon Press

Kirschner, Teresa J. (1993): "Exposición y subversión del discurso hegemónico en pro de la conquista en El Nuevo Mundo de Lope de Vega". In: Campbell, Ysla (ed.): Actas del I Congreso de la Asociación Internacional de Teatro Español y Novohispano de los Siglos de Oro (18-21 de marzo de 1992, Ciudad Juárez). El escritor y la escena. Cd. Juárez, México: Universidad Autónoma de Ciudad Juárez, 45-58

Lemartinel, Jean; Minguet, Charles (1980): El nuevo mundo descubierto por Cristóbal Colón. Comedia de Lope de Vega Carpio. Lille: PU de Lille

Lotman, Yuri M. (1999): Cultura y explosión. Lo previsible y lo imprevisible en los procesos de cambio social (Span. trans.). Barcelona: GEDISA

Lotman, Yuri M. (1985): La semiosfera. L'asimmetria e il dialogo nelle strutture pensanti (Ital. trans.). Venezia: Marsilio

Lotman, Yuri M. (1980): Testo e Contesto (1974-80) (Ital. trans.). Roma-Bari: Laterza

Lozano Miralles, Helena (2005, forthcoming): "Cuando el traductor empieza a inventar". In: Capanaga, Pilar; Fernández García, María Isabel (eds.): Estudios de neología. Bologna: Gedit

Martín Iniesta, Fernando (1997): "La falsa muerte de Jaro el negro". In: Serrano, Virtudes (ed.) (2004): Teatro breve entre dos siglos. Madrid: Cátedra

Martinell-Gifre, Emma (1988): Aspectos lingüísticos del descubrimiento y de la conquista. Madrid: Consejo superior de Investigaciones Científicas

Menéndez Pelayo, Marcelino (1949): "El Nuevo Mundo descubierto por Cristóbal Colón". In: Menéndez Pelayo, Marcelino: Estudios sobre el teatro del Lope de Vega. Santander: Aldus, Vol. 34, 306-325

Poyatos, Fernando (2002a): Nonverbal Communication across Disciplines. Volume 1: Culture, sensory interaction, speech, conversation (Eng. trans.). Amsterdam-Philadelphia: John Benjamins

Poyatos, Fernando (2002b): Nonverbal Communication across Disciplines. Volume 3: Narrative literature, theater, cinema, translation (Eng. trans.). Amsterdam-Philadelphia: John Benjamins

Restall, Matthew (2003): Seven Myths of the Spanish Conquest. New York: Oxford University Press 
Rodrigo Alsina, Miquel (1999): Comunicación intercultural. Barcelona: Anthropos

Rozas, Juan Manuel (1976): Significado y doctrina del arte nuevo de Lope de Vega. Madrid: Sociedad General Española de Librería

Sanchis Sinisterra, José (2002): La escena sin límites. Fragmentos de un discurso teatral. Ciudad Real: Ñaque

Scholem, Gershom (2001): Sabbetay Sevi. Il messia mistico (Ital. trans.). Torino: Einaudi

Shannon, Robert M. (1989): Visions of the New World in the Drama of Lope de Vega. New York-Bern: Peter Lang

Todorov, Tzvetan (1982): La conquête de l'Amérique. La question de l'autre. Paris: Editions du Seuil

Thürlemann, Félix (1980). "La fonction de l'admiration dans l'esthétique du XVII ${ }^{\mathrm{e}}$ siècle". In: $A S D$, II, 11 


\section{A Appendix}

The activity of the university Spanish theatre workshop started in the academic year 1992/1993 under the supervision and coordination of Isabel Fernández. Since 2004, three young research assistants (Mercedes Ariza, Claudio Bendazzoli and Maria Giovanna Biscu) have been helping in the coordination of the workshop.

By exploring different subjects and themes in accordance with students' needs, work was done on intersemiotic translation, adaptations of existing plays or collective creations written by all the participants. In the last fifteen years, 17 performances have been staged and presented to the Italian audience during a night entirely devoted to university theatre in foreign languages. Since the academic year 2003/2004, the performances of the university Spanish theatre workshop, as well as the performances of all the other foreign-language theatre workshops, ${ }^{27}$ have formed part of the international cultural event known as the Cantiere Internazionale Teatro Giovani (International Youth Theatre Workshop), organised in collaboration with Harvard University and Columbia University.

\section{A.1 List of the Performances}

- 1993 Mafalda (Quino, intersemiotic translation). Teatro Astra, Forlì

- 1995 Bajarse al moro (José Luis Alonso de Santos, adaptation). Teatro Astra, Forlì

- 1996 Jaque (texts by Jorge Luis Borges, Francisco de Quevedo, Mario Benedetti, Octavio Paz, Jaime Gil de Biedma, Leopoldo M. Panero). Teatro Testori, Forlì

- 1997 Ceguera de amor (Maruja Torres, intersemiotic translation). Teatro Testori, Forlì

- 1998 Entremés a la Don Juan (texts by Miguel de Cervantes, Tirso de Molina, José Zorrilla, Gonzalo Torrente Ballester). Teatro Testori, Forlì

- 1999 iOh vida! (Abilio Estévez, intersemiotic translation). Teatro Testori, Forlì

- 2000 La busca de Averroes (Jorge Luis Borges, intersemiotic translation). Teatro Testori, Forlì

\footnotetext{
27 At the Advanced School for Interpreters and Translators of the University of Bologna at Forlì there are six theatre workshops that work during the whole academic year to prepare performances in a foreign language (Spanish, English, French, German, Russian, Japanese), while one workshop presents performances in the mother-tongue of our students, i.e. Italian. The university theatre workshops started their activity in 1992 and have acquired more and more importance through the years. Every year, around 100 students are engaged in this extracurricular activity.
} 
- 2001 Pez Luna con cafetera (collective creation). Teatro "Diego Fabbri", Forlì

- 2002 Lágrimas en lunavisión (translation and adaptation of short plays by Stefano Benni). Teatro "Diego Fabbri”, Forlì

- 2003 El vuelo de Clavileño (adaptation of texts by Miguel de Cervantes and Alfonso Sastre). Teatro Testori, Forlì

- 2004a Escena del teniente coronel de la guardia civil (Federico García Lorca). Aula Magna, SSLMIT, University of Bologna at Forlì

- 2004b Incertidumbres de un piano bajo amenazas de lluvia (María Isabel Fernández García). "Festa degli Uni-Versi-V(T)ari”. Parco Urbano "Franco Agosto", Forlì

- 2004c Un piano sin manos (texts by Federico García Lorca). Teatro "Diego Fabbri", Forlì

- 2005a El Nuevo Mundo descubierto por Cristóbal Colón (Lope de Vega, adaptation). Teatro "Diego Fabbri", Forlì

- 2005b Cristóbal Colón scopre la Nuova Romagna (Lope de Vega, adaptation). Festa provinciale dell'Unità, Forlì ( $4^{\text {th }}$ July, 2005)

- 2006 Terror y miseria en el primer franquismo (José Sanchis Sinisterra, adaptation). Teatro "Diego Fabbri", Forlì

- 2007 Veinte años no es nada (collective creation). Teatro "Diego Fabbri", Forlì 